\title{
SPROKKELINGEN UIT VERGEELDE BLADEN VAN EEN EEUW GELEDEN
}

\author{
DOOR
}

\section{A. HALLEMA}

De volgende, thans een eeuw oude krantensnippers over WestIndië mogen eveneens nog de aandacht onzer lezers hebben.

Uit Suriname schrijft men, dat op den 4den Julij van dit jaar 1833 de 57ste verjaardag van de bevrijding van Noord-Amerika te Paramaribo plegtig is gevierd met een feestbanket, waarop de scheepskommandanten van de schepen der beide natien, Hollandsche en Amerikaansche, en een deel der aanzienlijkste ingezetenen tegenwoordig waren. Op de tafel waren de busten van onzen Koning en van den generaal Washington, alsmede van den tegenwoordigen President Jackson en van de Prinsen van Oranje en Frederik geplaatst. Er werden toasten gebragt op het welzijn van de beide natien, op die der Nederlandsche Vorsten, ook op die van den generaal Chassé en de brave citadelverdedigers, de wederzijdsche land- en zeemagt, enz. Alle ter reede liggende schepen waren ter gelegenheid van den dag met vlaggen versierd.

Uit Calais wordt van den 1sten September gemeld, dat dien morgen het Hollandsch driemastschip Augusta, kapitein J. J. Remkes, van Amsterdam, van 600 ton, van Surinamen komende met eene lading suiker, katoen, enz., omtrent een half uur ten oosten der haven van Calais gestrand en in stukken geslagen is. Zes man van de équipage, waaronder den kapitein, zijn tijdig genoeg uit zee gered en in het leven terug geroepen, de elf overigen waren ongelukkig in de golven omgekomen.

In de Curaçaosche Courant van den 31sten Augustus vindt men het volgende artikel. De vaste kust (Columbia) geniet eenen diepen vrede; doch de akkerbouw is er steeds kwijnende, daar de landbouwende klasse meestal in den lang gerekten oorlog is om- 
gekomen; het gouvernement spant echter zijn krachten in, om de landbouwende bevolking aan te moedigen; het afschaffen der tienden en andere geestelijke privilegiën zal daar zeer veel aan toebrengen. De Aartsbisschop en andere geestelijken zijn hierover ontevreden en men zeide, dat zij weder de wijk naar Curaçao zouden nemen, doch zulks heeft tot heden geen plaats gehad.

Het gouvernement van Venezuela heeft met vele Amerikaansche scheepskapiteins een verdrag aangegaan, om inboorlingen der Canarische eilanden, hier Islenos (eilandbewoners) genaamd, naar Venezuela over te voeren. De ondervinding heeft geleerd, dat de Islenos de geschiktste menschen zijn voor den landbouw in Venezuela; zij zijn daar, wat de Westphalingers voor Holland zijn, namelijk, regte werklieden. De Negers hebben geene konstbehoeften en werken niet meer dan hetgeen zij aan voedsel noodig hebben en daartoe is in eene zoo vruchtbare aarde weinig werk noodig; daarenboven zijn zij te vreezen, wijl jaloerschheid of afkeer tegen een bestuur van blanken diep bij hen ingeworteld zit. De Indianen beminnen de rust; de blanken kunnen in een heet gewest geen akkerwerk verrigten. De Islenos, die in vroegeren tijd aangekomen zijn, waren in weinige jaren door vlijt en aanhoudende inspanning welgezeten inwoners geworden. Het gouvernement betaalt hun hunnen overtogt, geeft hun land om te bebouwen en de noodige akkergereedschappen; ook blijven zij eenigen tijd van de belasting bevrijd. Van de West-Indische eilanden ontvangt Venezuela niet die bevolking, op welke men gehoopt had; de vrije lieden, die zich daar neer zetten, doen handel in het klein of oefenen ambachten uit, doch geen landbouw. De vaartuigen met Columbiaansche vlag zijn meestal met zeevolk uit Curaçao bemand. Eenige blanken, ingezetenen van Curaçao, hebben beproefd, om vrije lieden van Curaçao, die in armoede en gebrek wegens droogte en overgroote bevolking, verkeerden, naar de overkust over te brengen, waar zij een stuk gronds gekocht hadden. De proef is mislukt; deze Negers werken niet meer dan hun goed dunkt en er zijn geene dwangmiddelen om hen tot den arbeid te noodzaken.

Het gouvernement heeft verder besloten, om het lijk van den bevrijder Simon Bolivar van St. Martha naar Carracas te doen overbrengen, alwaar een gedenkteeken te zijner eer zal opgerigt worden, onder hetwelk zijn stoffelijk overschot zal rusten en verder, dat zijn sterfdag als een jaarlijksch treurfeest zal gevierd worden". 